\title{
The Battle of Barton Moss
}

In November 2013 a group of environmental activists set up camp at Barton Moss, Salford to protest against exploratory drilling at IGas's proposed hydraulic fracturing (fracking) well. The protests involved daily slow walks in front of trucks along Barton Moss Road into the drilling site that lasted until April 2014 when the company stopped drilling. During this period their campaign succeeded in overcoming the resistance of the local council, Greater Manchester Police (GMP), the drilling company IGas and one of the largest landowners in the North of England Peel Holdings - galvanising local activist groups in Greater Manchester and politicizing the wider community.

Having spent 3 to 4 days a week for the duration of the protest documenting the camp and the daily protest walks with photographs and interviews (interviews with protestors have been anonymised) this chapter looks at the impact the protest had and the innovative methods used to achieve its successes.

The campaign involved protest walks on Barton Moss Road by between 30 and 100 people twice a day and four days a week, in front of lorries as they entered and left the drilling site. This chapter looks at the protests relationship to the Occupy movement and will consider how its more active methods of protest gave a real sense of achievement to each and every protestor, revealed much about the mechanisms of the state in its policing of the protest and created a camaraderie that brought together a diverse range of activist groups.

These direct actions were soon proven to be legal in court and so effectively occupied a space in the legal system that forced the state and the various companies involved into greater and greater acts of desperation to try and stop the protests. The chapter looks at how this politicised the wider community and how networks of people and organisations were drawn into the protests bringing a sophisticated understanding and expertise that enabled the successes.

In some ways the protest camp at Barton Moss evolved out of the Occupy movement of 2011, with several protestors involved having participated in various Occupy camps around the UK. Having said this, many involved in the protests at Barton Moss had little knowledge of Occupy; indeed many had little experience of activism at all. The legacy of Occupy is varied but those who were involved in it learnt from the experience and used this as they have moved forward. One protestor who stayed at the Barton Moss Camp explained:

"Occupy has got a lot to answer for. The nock on effects of what happened at Occupy still resonates today. If you go to any eviction hearing for activists they will automatically refer to the City of London's eviction of Occupy. That camp was there to show that people weren't happy and were ready to start rising up saying we are not going to move unless you change... Occupy may not have worked the way that people wanted it to work because it was the first time many of us had done anything like that. And to be able to learn you have got to make mistakes. It didn't work in the 
way that the organisers wanted it to but it has worked through its knock on effects. We have learnt from those mistakes but as well as that it brought a lot of people together that wouldn't have been together without it. It is through these things that we have learnt what to look out for and what we are not going to do in the future and how we can keep getting the message across."

The fire that Occupy started is still burning, and protests such as those at Barton Moss are evidence of this but there are clear distinctions between these two protests. The organisers behind Occupy recently tried to recreate the scenes of 2011, this is moving in a different direction to many that were involved in the UK camps who have continued with its ideas but not its label. It is important not to see the protests at Baron Moss as a continuation of Occupy but as a movement that carries some of its memories.

There are a number of distinct differences between the anti-fracking protests at Barton Moss and the Occupy protest camps in 2011. The first is that the protests at Barton Moss were time and issue-specific; it opposed exploratory drilling that took place over a bounded period of time. In response, the landowners - Peel Holdings - made numerous attempts to have the camp evicted. These actions can be understood as part of a broader attempt by the British Government and corporations to stifle protests and dissent using the legal system. In contrast to the Occupy camps, the protestors managed to avoid eviction and keep the camp at the site until the drilling had finished. At this point the protestors removed the camp and the site was cleaned up and left as it was found. This created a sense of victory and led to a palpable sense of optimism among those involved.

The second perhaps more significant difference was the space the protest occupied. At Barton Moss the protesters not only occupied a space with their tents but also the space in front of the convoys of trucks entering the drilling site. Not by creating a blockade in front of the trucks but by simply exercising their legal right to walk along a public footpath. There were numerous forms of direct action that took place at Barton Moss but crucially, this one, walking along a public footpath, was an everyday activity that anyone could participate in and served to disrupt IGas's exploratory drilling at Barton Moss. This action also made it difficult for GMP to use the legal system against the protestors as it occupied a space in the system where it could not be criminalised. This interrupted the states ability to use the legal system to control dissent.

What happened at Barton Moss didn't just make fracking visible to the general public. It also made the mechanisms of the state visible, and not just visible but something experienced and tangible. Concepts about the relationship between the state and big business are abstract and devoid of meaning in most peoples lives. It is only when we experience oppression and injustice that we truly understand what it means. At Barton Moss people experienced the oppressive nature of state, at the hand of GMP, and realised that this was actually a state apparatus working to the benefit of a large corporation and against the people to supress their opinions. This was transformative.

\footnotetext{
1 Taken from telephone interview on January $20^{\text {th }} 2015$ with a protester who stayed on the camp at Barton Moss and is from Greater Manchester
} 
The action that proved to be the catalyst for all of this was the daily walks in front of the IGas convoys, occupying the footpath and interrupting IGas's trucks as they tried to enter the drilling site. The policing of the anti-fracking protests have been compared to the miner's strike ${ }^{2}$ but the difference here was the economic power was with those who were protesting. It is this tactic that for many revealed the states relationship to big business and how its role at Barton Moss was to ensure that fracking could be profitable even if its own actions were unlawful. The slow walks along Barton Moss Road exposed the states attempts to criminalise protest and forced it into making more and more mistakes in a way that has echoes of Emmanuel Levinas's anarchic ethics through interrupting the language of the established ethical framework. ${ }^{3}$

The slow walks, reminiscent of a situationist prank ${ }^{4}$, ruptured the normalising effects of modernity that penalises resistance and revealed the manner in which the legal system was being used as an apparatus to ensure the fracking industry was facilitated at any cost. When GMP desperately tried to criminalise the actions of the protestors slow walking the IGas trucks into the drilling site the system had no law to suit its own intentions. This interrupted the normalising that takes place through the legal system as a means of control.

What was significant in these moments is that you didn't need a political education to understand what was happening. Anyone taking part or witnessing these events knew what was going on. They could feel it; they could see it and they could hear it. Each time an arrest on a new charge for the slow walks ended up in court the charges were proven to be unlawful. The absurdity, brutality and injustice that people experienced revealed to everyone what was happening how the state was being used ${ }^{5}$.

\footnotetext{
2 In an article for Salford Star on February $6^{\text {th }} 2014$ Simon Pook of Robert Lizar Solicitors compared the policing of the protests at Barton Moss to the policing of the Miners Strike. "The last time I saw this sort of behaviour was in the Miners Strike of the 1980s where we saw identical police tactics being used, pushing at miners, brutalising peaceful protest...l am very, very concerned..."

"Solicitor Accuses Greater Manchester Police Of Political Policing At Barton Moss". Salfordstar.com. N.p., 2014. Web. 15 July 2014.

3 Levinas, Emmanuel. (1974) Otherwise than Being, or Beyond Essence. Duquesne University Press.

An ethical system for Levinas is located in and through language. He explores the way language interrupts itself in order to develop the idea of the ethical importance of interruption Language is an amphibology; it is made up of two parts, the saying and the said. Levinas suggests that it is the interweaving of the two, which "allows the ethical to signify within ontological language". Levinas suggests that "the said is the saying incarnated into a concrete world of meaning and history". It is through its location in a system that the said is made and given meaning; it is the material part of language that is written or spoken. The said is the logos, and imposes a finite meaning, the saying becomes trapped in the said, in the logos, and it is only through interruption that we get a sense of it.

4 Situationist International adopted numerous methods of turning expressions of the capitalist system against itself such as situations, happenings, situationist pranks and détournements

5 There were many brutal, absurd and unjust arrests at Barton Moss. These included the arrest of a Lawful Observer for drink driving whilst he was filming the arrest of another protestor on January $14^{\text {th }} 2014$ (https://www.youtube.com/watch?v=3gx|4ToNKGQ); the
} 
The protestors occupied a space in the legal system interrupting what the state said giving a sense of what it was saying. GMP were there to support IGas as it went about its business and someone walking in their way, no matter if their actions were lawful, could be arrested for doing so. There were arrests for various offences from Aggravated Trespass to Obstructing a Highway but GMP did not find a law that it could use as a charge that would stick against this method of protest and yet it continued to make arrests.

Over a six months period these increasingly desperate acts by the Greater Manchester Police to criminalise the actions of the Barton Moss protestors made it clear to anyone involved that the criminal justice system was being used to serve the interests of IGas. Despite these intentions this actually helped unite the people involved in the protests and galvanised support from other groups such as The Greater Manchester Association of Trade Councils (GMATUC). In a public letter to Tony Lloyd, the Greater Manchester Crime and Police Commissioner slated GMP over 'horrendous' policing at Barton Moss and spoke of protests being "criminalised in an attempt to silence dissent". The letter goes on to say that "There are citizens in our county who...now find it impossible to trust any man or woman wearing the GMP badge"6. Moreover, GMP's attempts to criminalize the protests had limited success: during the campaign there were 120 protestors arrested at Barton Moss and only 33 have been found guilty. Almost all the guilty verdicts are for charges separate from those associated with the slow walks such as charges for the other methods of direct action. ${ }^{7}$ Unfortunately, to date, GMP and the CPS have refused requests for the final figures on arrests ${ }^{8}$.

\section{Political Policing}

The first charges for the slow walks were for Obstruction of the Highway.

brutal arrest of Legal Observer Kris O'Donnel on January $20^{\text {th }} 2014$ whilst he tried to speak to an officer about a traffic offence (https://www.youtube.com/watch?v=9HWy4BegZqw) and the brutal arrest of Vanda Gillet who was injured during the arrest and refused medical attention for over an hour on February $15^{\text {th }} 2014$ (https://www.youtube.com/watch?v=AwU2zapAfJ8)

${ }^{6}$ Haworth, Susan. Policing Of Protest, Human Rights And Justice. 1st ed. Greater Manchester: Greater Manchester Association of Trades Councils, 2014. Web. 7 Aug. 2014 https://netpol.org/wp-content/uploads/2014/08/GMATUC-to-GMPCC-July-2014.pdf

${ }^{7}$ There were many forms of direct action during the protests at Barton Moss. As well as the slow walks there were various 'lock-on's' where protestors glued, locked or chained themselves to various things including steel pipes, fences, a red bus, a coffin and IGas trucks. The creativity of the protestors was sensational, on one occasion they managed to block the entrance to the drilling site with a 50ft blade from a wind turbine. Whilst these methods had a significant impact during the protest, they often served as retaliation to the brutality of some of the policing, it is important to distinguish between these methods of direct action and the slow walks

${ }^{8}$ The team behind the 'Keep Moving!' Report on the Policing of the Barton Moss Community Protection Camp have made numerous Freedom of Information Act requests for the final figures on arrests at Barton Moss. GMP and CPS have continued to refuse the teams requests for this information and they have an ongoing case with the Information Commissioner (IC) who is compelling the CPS to provide the information. At the end of April the CPS agreed to respond to their request (on threat of court action) but at the time of writing they were yet to hear from them or the IC. 
These cases collapsed following a hearing on 12th February 2014 at Manchester and Salford Magistrates' Court, when District Judge Qureshi ruled that the land in question was not a public highway. Later charges of obstructing a police officer were dismissed on the grounds that the arrests and the force used to 'push' protesters down the road were unlawful.

The third commonly used charge was aggravated trespass. At the time of writing many of the outstanding cases for this charge are still ongoing. However, the first of them, which is being used as a test case, has had similar results when both defendants were acquitted of the charge. In his report on the case, District Judge Sanders said the protestors were:

'Entitled to demonstrate, were entitled to walk along Barton Moss Road, had been generally compliant with the police, and their actions were specifically directed towards the object of their protest and not the wider public."9

The judge also went on to express how the nature of the policing had directly led to the arrests.
"Without any warning (or indeed clear rationale) the police changed their tactics and sought to significantly increase the pace of the protestors. Neither of the defendants wished to progress at this faster pace and resisted attempts to make them walk faster. In both cases, but separated by time, they had the misfortune to find themselves in front of PC Genge who interpreted this resistance as deliberate pushing back." ${ }^{10}$

Many arrests for the slow walks have been deemed unlawful and solicitor Simon Pook, of Robert Lizar's who represented many of the protestors arrested at Barton Moss on a pro bono basis, has called for a public inquiry into the policing. "Since November 2013, Richard Brigden and I advised the Court on the nature of Barton Moss Road. GMP continued to act without lawful authority for a number of months... We cannot permit, in an established democracy, police forces arresting and detaining citizens with the knowledge that their actions are themselves unlawful. Such a position only undermines confidence in the police and justice system."11

The sense that GMP had been serving the interests of IGas has been further exposed by the release of a Memorandum of Understanding ${ }^{12}$ between GMP, Salford City Council and IGas. It states that GMPs purpose was to "facilitate peaceful protest" and that "Police Officers must only use the minimum amount of lawful force", questionable given the video evidence and the number of dropped charges. It also sets out that IGas will "Lead on all media

\footnotetext{
9 District Judge Sanders,. Report Of Regina V Boris Roscin, John Wasilewski \& David Cohen. Manchester: The Manchester Magistrates' Court, 2016. Print

10 District Judge Sanders,. Report Of Regina V Boris Roscin, John Wasilewski \& David Cohen. Manchester: The Manchester Magistrates' Court, 2016. Print

11 Taken from telephone interview on September $24^{\text {th }} 2014$ with Simon Pook of Robert Lizar Solicitors

12 Greater Manchester Police,. Memorandum Of Understanding Between Greater Manchester Police, Greater Manchester Fire And Rescue Service, North West Ambulance Service, Salford City Council, Association Of Greater Manchester Authorities, Highways Agency, Igas, Peel Holdings/Estates And Manchester Barton Aerodrome.. Greater Manchester: Greater Manchester Police, 2014. Print.
} 
communication, both proactive and reactive". Simon Pook explains how the Memorandum of Understanding between IGas, Salford City Council and GMP shows that when GMP placed press releases in to the public domain they mislead the public. "As they stated GMP has to balance the right of the protesters and the rights of the community and workers. When in practice GMP appears to have given IGas direct access to their gold and silver command and IGas had the lead role in regards to press."13

The nature of the policing at Barton Moss seems to have followed on from the policing of the Anti-fracking protests at Cuadrillas exploratory drilling well at Balcombe in 2013. A review by Hertfordshire Constabulary and Essex Police found that the operation at Balcombe was flawed in several ways. With many of the charges from the protests at Balcombe being dropped in court the report states that the "absence of initial clear charging guidelines and standards may have unnecessarily added to the investigative process" and that they would "have also prevented the complications experienced in court." The report also claims that following a briefing between Sussex Constabulary and Cuadrilla the companies' response 'became a significant political/ economic issue related to subsequent involvement at a more senior political level." The report then goes on to criticise the relationship between Cuadrilla and Sussex police as needing to be "more transparent and less open to subsequent influence"14

The claims of 'political policing' at Barton Moss were due, in part, to the unnecessary high levels of policing and at times the brutality of the policing. It was also from the manner in which the police facilitated IGas in its business with police escorts to and from Barton Moss Road, stopping rush hour traffic to enable them to arrive in the area earlier. But significantly it is also due to the unlawful charges on which protestors were arrested with such a low proportion of the arrests resulting with a conviction.

The average conviction rate in the UK for public order offences stands at $93 \%$, yet the conviction rate for arrests during the Barton Moss protests are only $29 \%{ }^{15}$

A report by Centre for the Study of Crime, Criminalisation and Social Exclusion, Liverpool John Moores University and Centre for URBan Research (CURB), University of York examines in great detail the contradictions between the results of the police operation at Barton Moss and the stated intention for it by Greater Manchester Police:

"Given the low conviction rates, arrest under Operation Geraldton did not appear to have been carried out with a view to securing convictions. Rather, mass arrest and blanket bail served to create a de facto protest exclusion zone around the fracking

\footnotetext{
13 Taken from telephone interview on September $24^{\text {th }} 2014$ with Simon Pook of Robert Lizar Solicitors

14 DCC Adams,. Peer Group Review of Operation Mansell Anti Fracking protest Sussex Police. Hertfordshire: Hertfordshire Constabulary/Essex Police, 2014. Print

15 Gilmore, J., Jackson, W. \& Monk, H. (2016) 'Keep Moving!': Report on the Policing of the Barton Moss Community Protection Camp. Liverpool John Moores University
} 
site - an action that would otherwise have no basis in law as well as being a clear violation of the protesters' right to freedom of assembly under Article 11 of the European Convention on Human Rights."16

The report goes on to challenge the lawfulness of the arrests and questions the motives and the tactics of the police operations giving support to the belief held by many during the protests that the state was attempting to silence dissent and facilitate business.

\begin{abstract}
"The dubious legality under which arrests were carried out, evidenced by the readiness of the courts to challenge their legal basis, raises important questions about the extent to which the policing operation was driven by interests other than public order and crime prevention. It is clear from the above analysis that mass arrest was a central component of Operation Geraldton. The tactic served to physically clear protesters from the site, to deter others from attending the camp and to reinforce the construction of protesters as violent criminals and thereby legitimize the intensity of the policing operation." 17
\end{abstract}

What started as a campaign about fracking gained publicity because of the policing and with this public support for the campaign grew quickly. At the start of the campaign local opinion seemed to support fracking. BBC North West tonight ran a poll in December 2013 of which 34\% said they were opposed to fracking ${ }^{18}$. Then, in March 2014, local newspaper Manchester Evening News conducted a poll of which $73 \%$ said they were opposed to fracking ${ }^{19}$. Though they were conducted by two different media organisations, one can assume with some confidence that there was a severe shift in public opinion. This has put significant pressure on local politicians to oppose any future applications for fracking. The question then, is how can we account for the achievements of the anti-fracking protests at Barton Moss in Salford? The section below outlines the four most instrumental factors.

\title{
Methods of Protest
}

First and foremost was the slow walk method which involved walking with the trucks into the drilling site along Barton Moss Road. This delayed the companies' work-rate at the site, giving each protestor the sense that they had accomplished something significant. Providing protestors with a more positive and active experience than usual for a demonstration. It also helped generate a sense of camaraderie between them. A point echoed by local residents and campaigners from further a field that lived at the camp during the protests. In the words of one experienced protestor, who had been part of

\footnotetext{
16 Gilmore, J., Jackson, W. \& Monk, H. (2016) 'Keep Moving!': Report on the Policing of the Barton Moss Community Protection Camp. Liverpool John Moores University 17 Gilmore, J., Jackson, W. \& Monk, H. (2016) 'Keep Moving!': Report on the Policing of the Barton Moss Community Protection Camp. Liverpool John Moores University

18 "BBC Survey Suggests Support For Fracking In North West - BBC News". BBC News. N.p., 2014. Web. 13 June 2014 - http://www.bbc.co.uk/news/uk-england-25157239

${ }^{19}$ Thompson, Dan. "Three Quarters Of Mancunians Oppose Fracking, An M.E.N Survey Finds". men. N.p., 2014. Web. 13 June 2014 http://www.manchestereveningnews.co.uk/news/greater-manchester-news/three-quartersmancunians-oppose-fracking-6778067
} 
the Occupy London Stock Exchange protest and lived on the camp site at Barton Moss:

"The people of Salford turned out in support of our attempts to prevent IGas from fracking at Barton moss. They came every morning and walked in front of lorries with us, they were arrested with us, they were brutalised by police with us. When we were arrested they came to police stations in solidarity with us. They have attended our court cases to support us. Many locals offered showers, meals and beds for the night if we needed them. They brought us goods and blankets and all sorts of things the camp needed. The love and solidarity from local residents was amazing, in fact, I and many others formed strong bonds with many during the campaign at Barton moss, for me to such a degree that I couldn't leave them and remained in Manchester after our camp was disbanded. The love, support and solidarity shown to us by the local community, many of who were attending their very first protest was incredible. I have no doubt that if or when the frackers return this community will be more than ready to resist."

Local activists started the anti-fracking protests at Barton Moss and people from all over the country soon arrived to swell the number of people staying at the camp because of their own concerns about environmental degradation. On any night there would be between $20 \& 30$ protestors on the camp. Those staying at the camp were a mix of people from the local area and from further afield yet were labeled as being outsiders by both the police and the mainstream media. It was, however, the relationship between those staying at the camp and the wider community that was most significant in enabling the daily protests and the overall anti-fracking campaign to grow as a local resident explained:

"The relationship between the Protectors ${ }^{20}$ who came to live on the camp and the local residents was electric. Without the Protectors, locals wouldn't have had the knowledge and skills in how to survive, how to protest, legal knowledge, how to work together for the greater cause. Overall a phenomenal, dynamic experience that changed the lives of the local residents forever. It was like the cavalry coming. It was confirmation that we were doing the right thing in trying to save our Moss and showed we weren't alone in trying to stop the destruction of the environment. It made everything change and our determination to continue the fight is resolute."21

The second factor was the policing, specifically its often brutal nature and the many unlawful arrests. This generated a great sense of injustice that strengthened peoples' resolve. This is by no means a unique experience, but for many people their involvement at Barton Moss was their first ever protest. Unsurprisingly, many became politicised by the experience. A process expressed by this protestor:

"I'm a local resident, a peaceful person. I've never demonstrated before in my life, I'm not a politically aware person, just easy going, believe the Government, believe people, but do you know what? I am staggered with what I've seen... It breaks my heart." The previous day she had attended the protest to see what was going on "I came down, watched it go past, stood on the side and just cried, watching the police

\footnotetext{
${ }^{20}$ During the protests at Barton Moss the protestors who stayed at the camp came to be known as Protectors

21 Taken from an interview on March $20^{\text {th }} 2014$ with a protester who lives in Cadishead close to the camp at Barton Moss
} 
just pushing people down this footpath. Today I came and joined the group." 22

Another protestor, a local resident who regularly engaged in the protests walks, emphasized the idea that the brutal and unjust nature of the policing merely increased the resolve of the local community. His first interest in the protest was due to the dangers of fracking. But after seeing some of the videos of the protest decided to go and find out what was going on for himself. He spoke about how the policing made it more difficult to protest.

\begin{abstract}
"It was very, very congested which created loads of confrontation. At the end when I did my direct action and why I did my direct action, apart from being about the dangers of fracking, was because it felt like we were in a police state... I had tried many times to speak to the inspector about their behaviour and the way they would take it upon themselves to get us up the road in record time when the day before it had taken 45 minutes to an hour. As a direct result of that, and when they lost control and ran at people like myself and others, I thought I am going to make a stand because they shouldn't be able to push people around like that."23
\end{abstract}

This wasn't his first direct action ${ }^{24}$ but is an example of the growing number of people who took to this type of protest in frustration at the brutality of the policing. He explained:

"I have protested before but the only other direct action l've ever taken is to climb on a roof of a prison. Doing that you knew you were inviting violence and all sorts upon yourself. It is a result of massive frustrations for people to do that in prison and it is no different to what happened at Barton Moss. It felt like the right to protest had been taken away from us. But l'll tell you what really bothered me is the fear and desperation I used to see on peoples faces who don't come from my world; you get an affiliation to people like that. I'm not able to travel around the country to protest against this but if they come back l'll be there."25

The third factor was the camp itself. Having a physical space where people could meet, learn, organise and communicate gave the campaign a crucial focal point, with approx. 20 to 30 people staying there at any given time, This allowed those who were unable to stay and participate on a daily basis to come and engage at their convenience. The camp became a space of learning; many protestors discovered what their rights were during the slow walks through meeting legal advisors at the camp.

As an observer, it was quite clear that the community needed the camp for this protest to succeed. It acted like a crutch for many, enabling their protest to be more effective. Moreover, having a physical space meant that the local community was able to show their solidarity and support by providing the camp with donations of food, water, clothing, medicine and skills (such as construction, media and law) creating a large community of activists.

\footnotetext{
22 Taken from an interview on February $19^{\text {th }} 2014$ with a protester who lives in Irlam

23 Taken from an interview on April $19^{\text {th }} 2014$ with a protester who lives in Manchester

${ }^{24}$ For his direct action at Barton Moss he and another protestor glued their arms to the inside of a metal tube whilst they lay on the road forcing a delay to the convoy of trucks as they tried to enter the drilling site.

25 Taken from an interview on April $19^{\text {th }} 2014$ with a protester who lives in Manchester
} 
One protestor, for whom the anti-fracking protests at Barton Moss were his first protest and yet ended up living there, spoke about the camps significance.

\begin{abstract}
"The most important thing that the camp gives to the local community is that it is a visual of the issue. Once something appears the media comes down because it is new news and they want to know what is going on. Then you get it on your local TV news. Plus, if you look, all the community places are shut so people haven't got a place to gather any more... I've now been on the front line for a while and I can read each campaign. I am looking for ways to change public perception of issues and the only way to do that is making the issues visible. You have to make it visible for people to start moving." 26
\end{abstract}

Out of the camp grew a network that has galvanized the activist community in Greater Manchester. Martin Porter from Frack Free Greater Manchester ${ }^{27}$ explained.
"The success of the anti-fracking movement has sucked in experienced campaigners from Greenpeace, Reclaim the Power, FOE and so on but also, and this is what makes it unique as an environmental protest in my experience, the Trade Unions and other left wing political groups. These people didn't always get along, but I still don't think the big NGOs realise how important the links we have made in Manchester are. Non-hierarchical Direct Action people, Green NGOs and Trade Unions working together is very rare, and I think a huge innovation by Greater Manchester, all thanks to Barton Moss." 28

The fourth factor was the sophistication of the protest and the use of various media platforms. One protestor, who regularly attended the protest walks, was quick to point out.
"The location and the route was a flaw" he explained "but in actual fact they had never come up against the sort of sophistication of these protectors... which really laid them bare and made them look very, very amateurish, especially when compared to the policing that I know that goes on in communities." ${ }^{29}$

It is well documented that social media is beneficial for organizing protests as Martin Porter claimed, "the answer is Facebook and Twitter. We could never have organised everything ourselves. Even email couldn't keep up there was to much going on." But it is platforms like Bambuser ${ }^{30}$ that have perhaps proved most useful.

\footnotetext{
26 Taken from telephone interview on January $19^{\text {th }} 2015$ with a protester who stayed on the camp at Barton Moss and is from Liverpool

27 Frack Free Greater Manchester are a group of people from Greater Manchester, opposing any attempts to explore or undertake any High Volume slickwater Hydraulic Fracturing for extracting Coal Bed Methane, shale gas, or Underground Coal Gasification http://frackfreegtrmanchester.org.uk

28 Taken from telephone interview on May $19^{\text {th }} 2014$ with Martin Porter of Frack Free Greater Manchester

29 Taken from an interview on April $19^{\text {th }} 2014$ with a protester who lives in Manchester

30 Bambuser is a free to use live video streaming platform that enables users to upload live video recorded through mobile devices such as phones and tablets http://bambuser.com/v/4450505
} 
Bambuser enables you to live stream video from you mobile devices. Many protestors filmed protests to record police behaviour. The benefit to Bambuser is that the footage isn't recorded on to the device, so whilst phones can be confiscates as evidence for months until a case gets to court, by using Bambuser the footage is stored online and can be accessed by anyone straight away. GMP tried to counter this by targeting people live streaming, confronting them and trying to switch off the device whilst they questioned them. In some cases it was this footage that drew people to the protest out of their anger at what they were seeing.

The many hours of footage recorded in this way has been used by solicitors representing the protestors. Indeed the relationship between firms such as Lizars and the campaign has been very fruitful. Simon Pook explains how this worked, "We work very closely with the protestors, community groups, Green and Black Cross to ensure swift exchange of information. We can be seen at many camps across the country obtaining evidence and holding the police and state to account where their conduct is found wanting."

When the cavalry arrived in Salford at the start of the campaign no one knew what impact they would have but the state and the mainstream media were quick to try and construct a narrative about who they were. The perspective of GMP Chief Superintendent Mark Roberts was that "the majority of people who are arriving on the site are not there to protest against fracking but are there to disrupt and intimidate the local community and to antagonise police..." In many ways it was media platforms such as Bambuser along with independent publications such as Salford Star that enabled protestors to challenge this perception.

\section{Moving beyond the Battle of Barton Moss}

Those moments in front of the trucks at Barton Moss were in a small way truly revolutionary. The campaign grew out of the sense of injustice in the way GMP were oppressing people's protests about fracking. With its generosity, courage and commitment the community that grew out of the protests at Barton Moss has changed the political landscape in Greater Manchester.

Labelled in derogatory terms by the mainstream media as 'professional protestors' - seemingly intended to perpetuate the narrative of them being self-serving scroungers and an enemy of the community - the local communities experience has been of people engaged in politics out of conviction, something in stark contrast to the many career minded and well salaried 'professional politicians' who have lost the trust and support of so many local people. The community that grew out of the protests at Barton Moss has gone on to galvanise the wider community engaging with various other campaigns.

Since Barton Moss I have documented a number of the protests that have benefited from the networks that grew from it. The homelessness campaign is one of the big campaigns people from Barton Moss have been involved in. There are people from Barton Moss in Nottingham doing the live streaming of 
the homeless camp there. There have been others running homeless camps on the streets and in occupied buildings in Manchester. There are camps that have set up to tackle climate change in North Wales, Cheshire, Central Lancashire, East Yorkshire, South Yorkshire and Fylde. There were actions at the Tory Party Conference in Manchester, the NHS demos and so much more.

What the anti-fracking campaign at Barton Moss has done for the North is create a movement that is spreading and this has a clear lineage to the Occupy movement. Occupy galvanised a whole new generation of activists and the anti-fracking campaign at Barton Moss has worked as a continuation of its ideas that have spread to other campaigns. One protester who has seen this process right through explained the significance of the protests at Barton Moss.
"What the anti-fracking campaign at Barton Moss has done is brought everyone under one roof and to realise that we are all fighting for the same thing. No matter what campaign you are fighting for we are all fighting for a redistribution of resources. We all just want things to be dealt out more evenly. We have got homeless people that we have helped to get housing who are now fighting on other campaigns. There are people who we couldn't get housed who have gone to anti-fracking sites and flourished. No matter what campaign we are working on it is always giving people the drive to go on and do something else." ${ }^{31}$

There are many people who have been politicised by the campaign at Barton Moss and have gone on to other camps and other campaigns and so this community keeps growing. One protestor from Liverpool, explained how the protest had changed his life:

\begin{abstract}
"It was the first time l'd ever been on a protest, l'd never even been to a local demonstration so Barton Moss did change my life. From what I learnt there it has taken me on to other things with campaigns all around the country. And from never having been on a protest before I have set up a protest camps at Upton in Cheshire and in East Yorkshire. I have spoken at public meetings in front of packed halls which six or seven months earlier was a million miles away in my life."32
\end{abstract}

\title{
Revitalising Social Movements
}

Those moments in front of the trucks at Barton Moss felt like an opening. A space where people from all walks of life had found themselves because of their fear for what fracking might do to their environment; and yet in this space peaceful protesters were treated by the state as a danger to society, a menace, a disease to be cured. It was a space from where people could clearly see the mechanisms of the state and its relationship to industry; A space where the motives of its institutions had never seemed clearer and yet a space where the response of the people, both everyday and transformative, changed everything. In this space the conditions were perfect for this virus to spread and impossible for it to be treated. This is no doubt due to the legal

\footnotetext{
31 Taken from telephone interview on January $20^{\text {th }} 2015$ with a protester who stayed on the camp at Barton Moss and is a Greater Manchester resident

32 Taken from telephone interview on January $19^{\text {th }} 2015$ with a protester who stayed on the camp at Barton Moss and is from Liverpool
} 
expertise that was made available and the courage, generosity and commitment of the protestors but it was only truly effective because so many could engage in such an effective manner.

In fifteen years of documenting social movements I have never experienced a campaign achieve so much. The impact it had on the wider community was incredible and needs to be learnt from. It drew many people in from all walks of life and everyone who slow walked those trucks into the IGas site knew they had achieved something and usually came back for more.

Whether it was their resistance to the oppressive force of GMP or the impact they were having on the fracking industry each slow walk felt like a battle won. When GMP forced protestors to walk at irrational and unsafe speed, rather than being intimidated the community grew in courage, commitment and size.

So many people feel disillusioned by the political process and demonstrating against the injustices can seem passive. What happened at Barton Moss was a far more meaningful form of protest that gave a real sense of achievement to each and every protestor and revealed much about the mechanisms of the state in its policing of the protest. It was this that politicised the wider community.

Some of the significant aspects of what happened at Barton Moss happened by chance. If Barton Moss Road had not been a public footpath the arrests may have been proved lawful. But whilst the sophistication of the protests at Barton Moss was impressive, a lot of this was still reactionary. Looking to the future, social movements must look for these gaps in the system and develop protests that expose the intentions of the state and its attempts to impose its will upon people on dubious moral grounds. This is already happening in some ways but the more ingenious the planning, the more enlightening the protest will be.

Campaigning on a single issue such as fracking will not change everything but methods such as these can. They are already spreading, with Nanas in Blackpool claiming victories against fracking and Focus E15 Mothers in East London fighting for social housing. If more campaigns learn from these tactics we may start to see some real changes. 